\title{
Patterns and controls of foliar nitrogen isotope composition on the Qinghai-Tibet Plateau, China
}

\author{
Yongchun Zhou • Xilei Cheng • Jiangwen Fan • \\ Warwick Harris
}

Received: 25 May 2015 / Accepted: 1 April 2016/Published online: 7 April 2016

(C) Springer International Publishing Switzerland 2016

\begin{abstract}
Background and aims Determine if relationships between temperature, precipitation and foliar nitrogen isotopes $\left(\delta^{15} \mathrm{~N}\right)$ observed in various ecosystems also operate in the high-cold Qinghai-Tibet Plateau; measure variation of foliar $\delta^{15} \mathrm{~N}$ with altitude, and examine relationships differences among plant functional groups (PFGs).

Methods Foliar $\delta^{15} \mathrm{~N}$ at 82 grassland sites were determined and grouped for PFGs to determine relationships with temperature, precipitation and altitude. Residual
\end{abstract}

Responsible Editor: Liz Shaw.

\section{Y. Zhou}

College of Resources and Civil Engineering, Northeastern University, No. 3-11, Wenhua Road, Heping District,

Shenyang 110819, China

X. Cheng

Liaoning Academy of Environmental Sciences,

Shenyang 110031, China

J. Fan $(\bowtie)$

Key Laboratory of Land Surface Pattern and Simulation, Institute of Geographic Sciences and Natural Resources Research, Chinese Academy of Sciences, 11A Datun Road, Chaoyang District,

Beijing 100101, China

e-mail: fanjw@igsnrr.ac.cn

J. Fan

e-mail: fanjiangwenigsnrr@126.com

W. Harris

Landcare Research, PO Box 69040, Lincoln 7640, New Zealand foliar $\delta^{15} \mathrm{~N}$ were used in regressions to eliminate effects of non-target variables. For relationships with potential breakpoints, piecewise regressions were used.

Results Relationships of foliar $\delta^{15} \mathrm{~N}$ with temperature and precipitation differed among PFGs. Foliar $\delta^{15} \mathrm{~N}$ of $\mathrm{C}_{3}$ species respectively increased and decreased with August temperature (TEM8) and precipitation (PRE8) across sites with TEM $8 \geq 9.95{ }^{\circ} \mathrm{C}$ and PRE $8<145.7 \mathrm{~mm}$, whereas it was invariant across sites with TEM $8<9.95{ }^{\circ} \mathrm{C}$ and PRE $8 \geq 145.7 \mathrm{~mm}$. Foliar $\delta^{15} \mathrm{~N}$ decreased with altitude. Conclusions Complex relationships of foliar $\delta^{15} \mathrm{~N}$ with climate factors suggest caution in its use to monitor nitrogen cycling. Although the altitude pattern of foliar $\delta^{15} \mathrm{~N}$ appeared to be mainly induced by temperature and precipitation, there are other altitude related factors in Qinghai-Tibet high elevations that influence foliar $\delta^{15} \mathrm{~N}$. Determining the functions of these factors provides foci for future research.

Keywords Altitude $\cdot$ Climate $\cdot$ Foliar $\delta^{15} \mathrm{~N} \cdot$ Plant functional groups · Grassland · Qinghai-Tibet Plateau

\section{Introduction}

Global climate change induced by natural and human factors is strongly influencing terrestrial ecosystems and changing their inherent natural processes, consequently threatening the environments humans occupy ( $\mathrm{Fu}$ et al. 2005). How to deal with this is a serious challenge for human society, and consequently understanding responses and adaptation of ecosystems to climate change 
is a prerequisite for addressing this challenge (IPCC 2007). Thus, investigations of effects of climate change on ecosystem carbon $(\mathrm{C})$ and nitrogen $(\mathrm{N})$ cycling are essential for understanding the response and adaptation of ecosystems to climate change. Consequently these investigations have become the leading fields and foci of climate change research.

Foliar $\delta^{15} \mathrm{~N}$ integrates several biogeochemical processes in ecosystem $\mathrm{N}$ dynamics. It has been demonstrated that it can serve as a proxy for terrestrial $\mathrm{N}$ cycling processes (Houlton et al. 2006; Mayor et al. 2014; Robinson 2001). Thus foliar $\delta^{15} \mathrm{~N}$ has been increasingly used in ecosystem $\mathrm{N}$ cycling studies to reveal patterns and controls of $\mathrm{N}$ cycling and to understand how $\mathrm{N}$ cycling responds to climate change (Craine et al. 2009; Houlton et al. 2006, 2007).

Considerable research has investigated effects of environmental, and especially climate factors, on foliar $\delta^{15} \mathrm{~N}$. There is evidence that foliar $\delta^{15} \mathrm{~N}$ declines with mean annual precipitation (MAP) (Amundson et al. 2003; Craine et al. 2009; Peri et al. 2012; Swap et al. 2004). Craine et al. (2009) found that this pattern applied to non-legumes but not legumes. Although most studies have found that foliar $\delta^{15} \mathrm{~N}$ increases with mean annual temperature (MAT) (Amundson et al. 2003; Liu et al. 2007), some studies have found that the relationship between foliar $\delta^{15} \mathrm{~N}$ and MAT is not a simple linear function. On the global-scale, Craine et al. (2009) found that foliar $\delta^{15} \mathrm{~N}$ increased or was invariant respectively with increasing MAT across sites with MAT $\geq-0.5{ }^{\circ} \mathrm{C}$ and MAT $<-0.5{ }^{\circ} \mathrm{C}$. At Dongling Mountain, Beijing, Liu et al. (2010) found that plant $\delta^{15} \mathrm{~N}$ decreased and increased respectively with MAT below and above $3.5^{\circ} \mathrm{C}$.

Previous studies have made considerable progress in understanding patterns and controls of foliar $\delta^{15} \mathrm{~N}$. However, these studies have been performed mainly in warm regions and for forest ecosystems (Fang et al. 2013; Houlton et al. 2006, 2007; Peri et al. 2012). There have been only a few studies for grassland ecosystems and particularly those of cold high-altitude regions.

Yang et al. (2013) have conducted relevant research on the Tibetan Plateau but further research is needed on aspects they did not consider. They considered only MAT and MAP as climatic controllers of foliar $\delta^{15} \mathrm{~N}$, and did not consider other altitude related factors. Altitudinal gradients provide unique opportunities to study the integrative effects of environmental factors and to determine which factors most affect plant $\delta^{15} \mathrm{~N}$. For climate factors, not only MAT and MAP but also atmospheric pressure (correspondingly atmospheric $\mathrm{CO} 2$ and $\mathrm{O} 2$ concentrations) changes with altitude, and this change is more obvious in high-altitude regions. Atmospheric $\mathrm{CO}_{2}$ concentration has been shown to have an important role in controlling the ecosystem $\mathrm{N}$ cycling by influencing $\mathrm{N}$ availability and gaseous $\mathrm{N}$ loss (Gill et al. 2002), and consequently plant $\delta^{15} \mathrm{~N}$ (Bassirirad et al. 2003).

Further, Yang et al. (2013) considered vegetation $\delta^{15} \mathrm{~N}$ as a whole and did not consider the variation of foliar $\delta^{15} \mathrm{~N}$ among plant functional groups (PFGs) or whether responses of foliar $\delta^{15} \mathrm{~N}$ to climate factors differ among PFGs. Lastly, they did not consider growing season temperature (GST) and precipitation (GSP) or mean temperature (TEM8) and precipitation (PRE8) in August, the period of peak annual growth. Especially, these factors can more accurately predict the effect of climate change on foliar $\delta^{15} \mathrm{~N}$.

The primary objectives of this study were (1) to investigate variation of foliar $\delta^{15} \mathrm{~N}$ among PFGs on the Qinghai-Tibet Plateau, including the life-forms of graminoids, forbs and shrubs; the taxonomic classes of monocotyledons and dicotyledons; and the family groups Poaceae, Cyperaceae, Leguminosae (legumes), Asteraceae, and other families combined; (2) to investigate relationships between foliar $\delta^{15} \mathrm{~N}$ and temperature, precipitation (not only MAT and MAP, but also growing season and August variables) and altitude in this region, and to test whether these relationships differed among PFGs and whether growing season variables, especially those during August have stronger relationships with foliar $\delta^{15} \mathrm{~N}$ than MAP and MAT; and (3) to identify the key climate controls of foliar $\delta^{15} \mathrm{~N}$ on the QinghaiTibet Plateau in order to improve prediction of effects of climate change on the ecosystem $\mathrm{N}$ cycles of the Plateau's grasslands.

\section{Methods}

Study area

Plant samples for determining foliar $\delta^{15} \mathrm{~N}$ were obtained from 82 grassland sites along northeast-southwest transects on the Qinghai-Tibet Plateau (Fig. 1).

The Qinghai-Tibetan Plateau, the largest and highest plateau of the Earth, is 2.5 million $\mathrm{km}^{2}$ in area, has an 


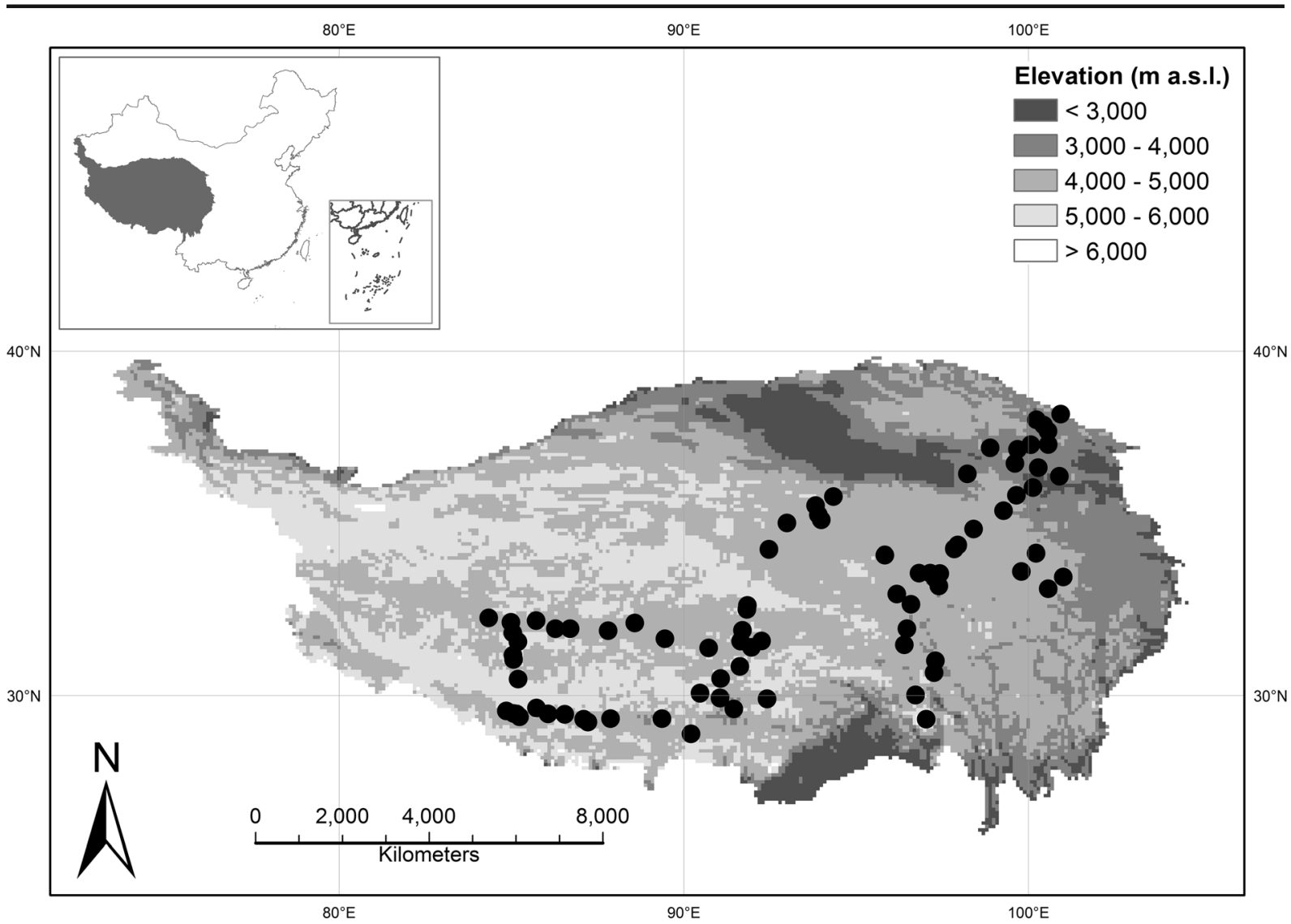

Fig. 1 Locations of the sample sites for grassland species foliar $\delta^{15} \mathrm{~N}$ on the Qinghai-Tibet Plateau, China

average elevation of about $4500 \mathrm{~m}$ and an alpine climate with severe long winters and short cool summers. MAP ranges from 100 to $800 \mathrm{~mm}$, and MAT mainly ranges between -6 and $9{ }^{\circ} \mathrm{C}$. Altitude of the Plateau increases from northeast to southwest and consequently atmospheric pressure decreases in the same direction. Grassland types of the Plateau are, in transition from east to west, alpine meadow, alpine meadow steppe, alpine steppe, alpine desert steppe and alpine desert. The main dominant species are the sedges Kobresia pygmaea, Kobresia tibetica, and Kobresia humilis, the grass Stipa purpurea, and the shrub Dassiphora fruticosa. The soils are simple, zonal types with alpine cold desert, alpine steppe and meadow soils the most widespread.

\section{Sampling}

$219 \mathrm{C}_{3}$ plant samples were obtained from the 82 sites during the peak annual growing periods of 2004 to 2007. To minimize influences of human disturbance (such as grazing), sample sites were fenced, not grazed in sampling year, and away from human habitation. Sites were separated from each other by about $50 \mathrm{~km}$ and their geographic positions recorded using Magellan GPS (Garmin, Kansas, USA). Mostly, three $1 \mathrm{~m} \times 1 \mathrm{~m}$ quadrats were randomly located within each sample site, but for sites with shrubs or subshrubs $5 \mathrm{~m} \times 5 \mathrm{~m}$ or larger quadrats and for alpine meadow sites $0.5 \mathrm{~m} \times 0.5 \mathrm{~m}$ quadrats were used. The dominant species in each quadrat were defined, and were separated and placed in different envelopes. The remaining species in each quadrat were put in another envelope. More information about the sampling is given in Zhou et al. (2013).

\section{Sample analysis}

Stable N isotope compositions of the leaf samples were determined at the central physicochemical laboratory of the Institute of Geographic Sciences and Natural Resources Research, Chinese Academy of Sciences, Beijing. Depending on leaf size, 3-20 leaves (mostly 5) from at least three different adult individual plants 
were selected for each species sample of each site. Leaves were washed with distilled water, air-dried, oven-dried at $80^{\circ} \mathrm{C}$ for $48 \mathrm{~h}$, and then milled to fine powder for analysis. ${ }^{15} \mathrm{~N} /{ }^{14} \mathrm{~N}$ ratios were determined by an isotope mass spectrometer (Finnigan MAT-253, Thermo Electron). Leaf $\delta^{15} \mathrm{~N}$ (\%) was calculated as:

$\delta^{15} \mathrm{~N}\left((\% \mathrm{o})=\left[\left(\mathrm{R}_{\text {sample }}-\mathrm{R}_{\text {standard }}\right) / \mathrm{R}_{\text {standard }}\right] \times 1000\right.$

where $R_{\text {sample }}$ and $R_{\text {standard }}$ are the ${ }^{15} \mathrm{~N} /{ }^{14} \mathrm{~N}$ ratio in the leaf and the standard, respectively. The universally accepted standard of atmosphere was used.

Meteorological data

Based on climate monitoring data of 108 climatic stations located across or around the Qinghai-Tibet Plateau, databases of mean daily temperature (MDT) and mean daily precipitation (MDP) were obtained by Anuspline interpolation with DEM as a covariate. Using MDT and MDP, we then calculated the mean monthly temperature (MMT), growing season temperature (GST), MAT, mean monthly precipitation (MMP), growing season precipitation (GSP) and MAP of our study sites during the sampling period. The QinghaiTibet Plateau growing season is from May to September.

Data analysis

In order to explore the variation of foliar $\delta^{15} \mathrm{~N}$ among PFGs, species were categorized into graminoids (grasses and sedges), forbs (herbaceous species other than graminoids), and shrubs according to life-form; into monocotyledons and dicotyledons according to taxonomic class; and into Poaceae, Cyperaceae, Leguminosae, Asteraceae, and other families combined. Covariance analysis, with climate factors and altitude as covariates, was conducted by a general linear model (GLM) to evaluate the difference of foliar $\delta^{15} \mathrm{~N}$ among PFGs. Based on the fact that foliar $\delta^{15} \mathrm{~N}$ of legumes do not vary with environmental factors significantly, our analysis regarding relationships between foliar $\delta^{15} \mathrm{~N}$ and temperature, precipitation and altitude were run for non-legumes only.

Foliar $\delta^{15} \mathrm{~N}$ was first analyzed with a GLM that include TEM8, GST, MAT, PRE8, GSP and MAP. TEM8 and PRE8 were found to explain a greater proportion of the variation of foliar $\delta^{15} \mathrm{~N}$ than mean annual or growing season variables, and the effect of mean annual or growing season variables on foliar $\delta^{15} \mathrm{~N}$ were almost indirectly induced by TEM8 and PRE8. Thus only TEM8 and PRE8 were used in subsequent analyses. Regression analyses were conducted to investigate the relationships between foliar $\delta^{15} \mathrm{~N}$ and site TEM8, PRE8 and altitude for 204 non-legume $C_{3}$ species combined and separately for graminoids, forbs, shrubs. In order to eliminate the covariation effect of PRE8 on relationships of foliar $\delta^{15} \mathrm{~N}$ with TEM8, we first calculated the residual of foliar $\delta^{15} \mathrm{~N}$ with respect to PRE8 and then conducted regression analyses between residual foliar $\delta^{15} \mathrm{~N}$ and TEM8. The same was done for the relationships between foliar $\delta^{15} \mathrm{~N}$ and PRE8. For the relationships of foliar $\delta^{15} \mathrm{~N}$ with TEM8 and PRE8 having potential breakpoints, piecewise linear regressions were used to fit these relationships.

To determine whether relationships between foliar $\delta^{15} \mathrm{~N}$ and altitude were induced by temperature and precipitation and whether there were other factors except temperature and precipitation having an effect on altitude pattern of foliar $\delta^{15} \mathrm{~N}$, we not only conducted regression analyses between altitude and foliar $\delta^{15} \mathrm{~N}$, but also residual foliar $\delta^{15} \mathrm{~N}$ after accounting for the variation explained by temperature and precipitation. Piecewise linear regressions were conducted in Origin (ver. 8.0; OriginLab, USA) and all other statistics computed in SPSS (ver.18.0; SPSS Inc., USA).

\section{Results}

Foliar $\delta^{15} \mathrm{~N}$ on the Qinghai-Tibet Plateau

Foliar $\delta^{15} \mathrm{~N}$ values ranged from -2.49 to $15.57 \%$, with $68 \%$ of these values within the range 2 to $8 \%$ (Fig. 2).

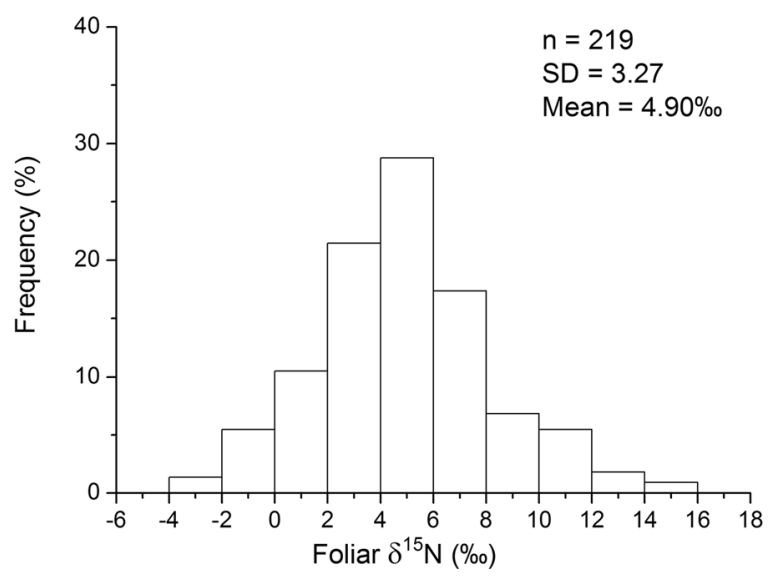

Fig. 2 Frequency distribution of foliar $\delta^{15} \mathrm{~N}$ values for $\mathrm{C}_{3}$ species on the Qinghai-Tibet Plateau 
The variation coefficient was $66.73 \%$ and the mean foliar $\delta^{15} \mathrm{~N}$ was $4.90 \%$ (Fig. 2).

Mean foliar $\delta^{15} \mathrm{~N}$ values of the plant functional groups are presented in Table 1. Independently of environmental factors, foliar $\delta^{15} \mathrm{~N}$ of legumes was significantly lower than that of non-legume families, whereas there were no significant differences between nonlegume families except "other families". Considering the significant difference between foliar $\delta^{15} \mathrm{~N}$ of legumes and other non-legume families, legumes were excluded when comparing foliar $\delta^{15} \mathrm{~N}$ among lifeforms and classes. Independently of habitat, foliar $\delta^{15} \mathrm{~N}$ of graminoids was significantly higher than that of forbs, whereas foliar $\delta^{15} \mathrm{~N}$ of shrubs was not significantly different from that of graminoids and forbs. There was no significant difference between foliar $\delta^{15} \mathrm{~N}$ of monocotyledons and dicotyledons, but after accounting for co-variation effects of environmental factors, foliar $\delta^{15} \mathrm{~N}$ of dicotyledons was significantly lower than that of monocotyledons.

Relationships between foliar $\delta^{15} \mathrm{~N}$ and precipitation and temperature

Foliar $\delta^{15} \mathrm{~N}$ of $\mathrm{C}_{3}$ species did not increase monotonically with TEM8 (Fig. 3a). For sites with TEM $8<9.95{ }^{\circ} \mathrm{C}$, foliar $\delta^{15} \mathrm{~N}$ showed no trend with TEM8, whereas foliar $\delta^{15} \mathrm{~N}$ increased linearly with TEM 8 at a rate of $1.274 \%{ }^{\circ} \mathrm{C}^{-1}$ when TEM $8 \geq 9.95{ }^{\circ} \mathrm{C}$ (Fig. 3a). Temperature patterns of foliar $\delta^{15} \mathrm{~N}$ differed among life-forms (Fig. 3b d). Graminoids had similar temperature patterns to $\mathrm{C}_{3}$ species, with a breakpoint at $9.83{ }^{\circ} \mathrm{C}$
(Fig. 3b). Foliar $\delta^{15} \mathrm{~N}$ of forbs and shrubs increased linearly with TEM8, however the increasing rate of shrubs with TEM8 was larger than that of forbs $\left(1.282 \%{ }^{\circ} \mathrm{C}^{-1}\right.$ vs. $\left.0.456 \%{ }^{\circ} \mathrm{C}^{-1}, p=0.01\right)$ (Fig. $3 \mathrm{c}$ and d).

Foliar $\delta^{15} \mathrm{~N}$ of $\mathrm{C}_{3}$ species decreased significantly with PRE8 at the rate of $0.0328 \% 100 \mathrm{~mm}^{-1}$ across sites with PRE8 $<145.7 \mathrm{~mm}$, when PRE8 $\geq 145.7 \mathrm{~mm}$, foliar $\delta^{15} \mathrm{~N}$ increased with PRE8, however this trend was not significant (Fig. 4a). As with temperature patterns, precipitation patterns of foliar $\delta^{15} \mathrm{~N}$ also differed among PFGs. Graminoids had similar precipitation patterns to $\mathrm{C}_{3}$ species, with a breakpoint at $142.49 \mathrm{~mm}$ (Fig. 4b). Foliar $\delta^{15} \mathrm{~N}$ of forbs significantly decreased with PRE8 (Fig. 4c), but foliar $\delta^{15} \mathrm{~N}$ of shrubs showed no trend with PRE8 (Fig. 4d).

GLM analyses showed that temperature and precipitation together explained 33.5, 29.9, 19.1 and $72.8 \%$ of the variation of foliar $\delta^{15} \mathrm{~N}$ for $\mathrm{C}_{3}$ species, graminoids, forbs and shrubs, respectively, with the largest proportion contributed by TEM8 for $\mathrm{C}_{3}$ species $(23.58 \%$ ), graminoids $(17.57 \%)$, and shrubs $(72.79 \%)$, and by PRE8 for forbs (10.55\%) (Table 2).

\section{Altitudinal pattern of foliar $\delta^{15} \mathrm{~N}$}

Foliar $\delta^{15} \mathrm{~N}$ of $\mathrm{C}_{3}$ species, graminoids and shrubs decreased significantly with altitude (Fig. 5a, c and g), but the relationship between foliar $\delta^{15} \mathrm{~N}$ and altitude for forbs was not significant (Fig. 5e). However, after accounting for variation in foliar $\delta^{15} \mathrm{~N}$ explained by temperature and precipitation, there were still significant negative relationships between altitude

Table 1 Variation of foliar $\delta^{15} \mathrm{~N}$ among plant functional groups (PFGs) on the Qinghai-Tibet Plateau

\begin{tabular}{llll}
\hline Categories & PFGs & Mean \pm SD (\%) & Mean \pm SD (\%o) excluding legumes \\
\hline Life-forms & Graminoids & & $5.34 \pm 3.09 \mathrm{a}(5.40 \mathrm{a})$ \\
& Forbs & & $3.75 \pm 2.93 \mathrm{~b}(4.24 \mathrm{~b})$ \\
& Shrubs & & $5.77 \pm 4.83 \mathrm{ab}(4.24 \mathrm{ab})$ \\
Classes & Monocotyledons & & $5.26 \pm 3.10 \mathrm{a}(5.34 \mathrm{a})$ \\
& Dicotyledons & & $4.50 \pm 3.77 \mathrm{a}(4.31 \mathrm{~b})$ \\
Families & Poaceae & $5.91 \pm 2.83 \mathrm{a}(5.77 \mathrm{a})$ & \\
& Leguminosae & $3.05 \pm 1.78 \mathrm{c}(2.41 \mathrm{c})$ & \\
& Cyperaceae & $5.00 \pm 3.22 \mathrm{ab}(5.23 \mathrm{ab})$ & \\
& Asteraceae & $5.24 \pm 4.55 \mathrm{abc}(4.53 \mathrm{ab})$ & \\
& Other families & $3.88 \pm 2.97 \mathrm{bc}(4.23 \mathrm{~b})$ & \\
\hline
\end{tabular}

Different letters within grouping categories indicate significant differences at $P<0.05$. Data in brackets are the standardized mean value by temperature, precipitation and altitude. For comparison of life forms and classes the mean values do not include legumes 
Fig. 3 Relationships between foliar $\delta^{15} \mathrm{~N}$ and temperature for plant functional groups (PFGs) on the Qinghai-Tibet Plateau. After accounting for the variation in foliar $\delta^{15} \mathrm{~N}$ explained by mean August precipitation (PRE8), the relationships between residual variation in foliar $\delta^{15} \mathrm{~N}$ and mean August temperature (TEM8) are shown. (a) $\mathrm{C}_{3}$ species; (b) graminoids; (c) forbs; (d) shrubs
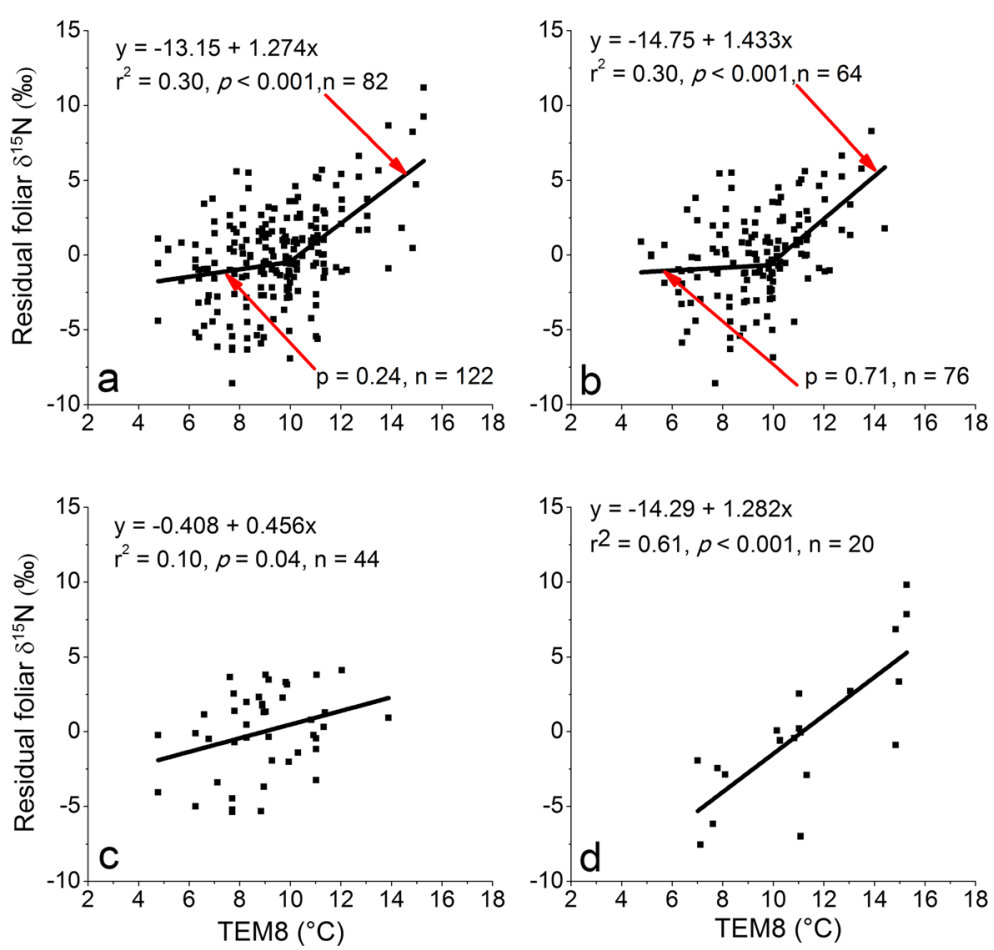

and residual foliar $\delta^{15} \mathrm{~N}$ for $\mathrm{C}_{3}$ species and graminoids (Fig. $5 b$ and d), but there were no significant correlations between altitude and residual foliar $\delta^{15} \mathrm{~N}$ for forbs and shrubs (Fig. $5 \mathrm{f}$ and $\mathrm{h}$ ). These results indicate that apart from temperature and precipitation, there are other factors related to altitude that affect foliar $\delta^{15} \mathrm{~N}$ of $\mathrm{C}_{3}$
Fig. 4 Relationships between foliar $\delta^{15} \mathrm{~N}$ and precipitation for plant functional groups (PFGs) on the Qinghai-Tibet Plateau. After accounting for the variation in foliar $\delta^{15} \mathrm{~N}$ explained by mean August temperature (TEM8), the relationships between residual variation in foliar $\delta^{15} \mathrm{~N}$ and mean August precipitation (PRE8) are shown. (a) $\mathrm{C}_{3}$ species; (b) graminoids; (c) forbs; (d) shrubs
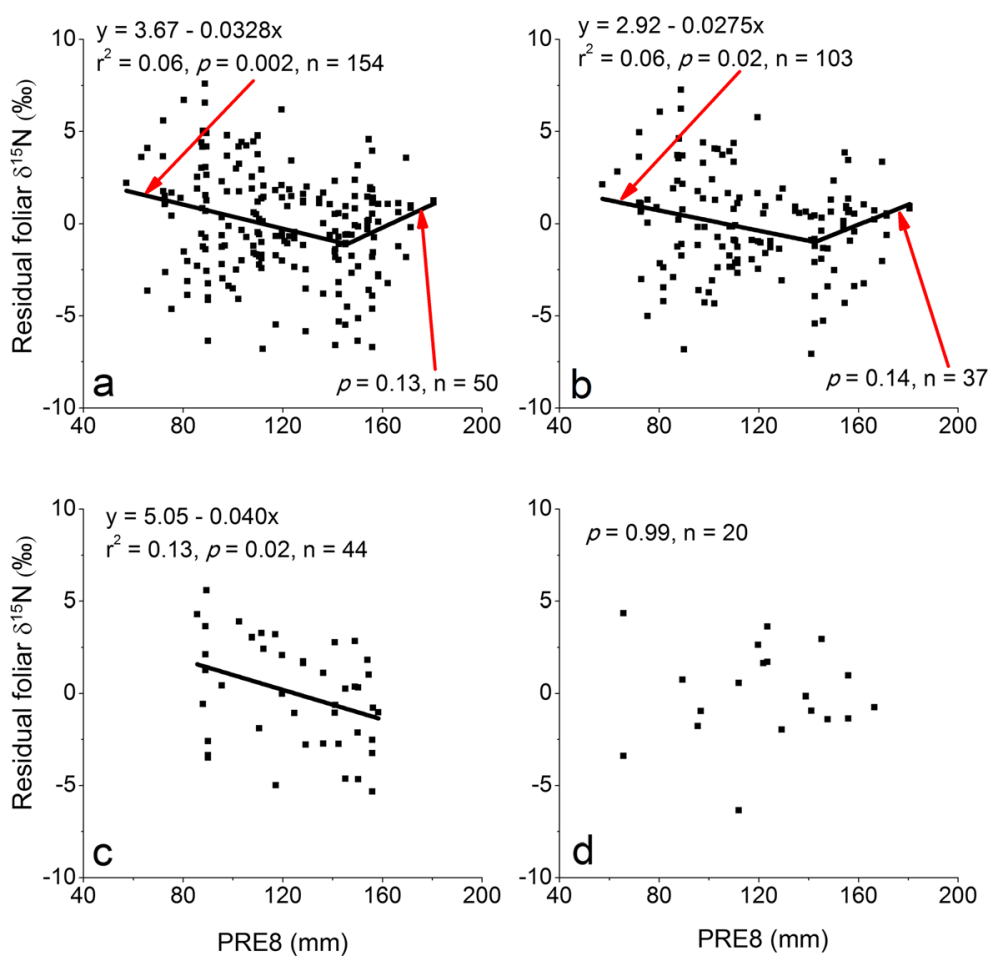
Table 2 Summary of results of general linear models (GLMs), showing the effects of temperature and precipitation on foliar $\delta^{15} \mathrm{~N}$ of plant functional groups (PFGs) on the Qinghai-Tibet Plateau

\begin{tabular}{|c|c|c|c|c|c|c|c|c|c|c|c|c|}
\hline \multirow[t]{2}{*}{ Variable } & \multicolumn{3}{|c|}{$\mathrm{C}_{3}$ species } & \multicolumn{3}{|c|}{ Graminoids } & \multicolumn{3}{|l|}{ Forbs } & \multicolumn{3}{|l|}{ Shrubs } \\
\hline & MS & $\mathrm{SS}(\%)$ & $P$ value & MS & $\mathrm{SS}(\%)$ & $P$ value & MS & $\mathrm{SS}(\%)$ & $P$ value & MS & $\mathrm{SS}(\%)$ & $P$ value \\
\hline TEM8 & 527.34 & 23.58 & $<0.001$ & 233.42 & 17.57 & $<0.001$ & 31.43 & 8.53 & 0.04 & 322.88 & 72.78 & $<0.001$ \\
\hline TEM8 Break & 0.16 & 0.01 & 0.88 & 1.02 & 0.08 & 0.70 & & & & & & \\
\hline PRE8 & 72.32 & 3.23 & 0.002 & 24.40 & 1.84 & 0.06 & 38.89 & 10.55 & 0.03 & 0.00 & 0.00 & 0.99 \\
\hline PRE8 Break & 19.08 & 0.85 & 0.11 & 39.27 & 2.96 & 0.02 & & & & & & \\
\hline TEM $8 \times$ TEM 8 Break & 98.33 & 4.40 & $<0.001$ & 75.92 & 5.72 & 0.001 & & & & & & \\
\hline PRE8 $\times$ PRE8 Break & 32.86 & 1.47 & 0.038 & 22.66 & 1.71 & 0.07 & & & & & & \\
\hline
\end{tabular}

TEM8, mean August temperature; TEM8 Break, a categorical separation of sites based on TEM8 of $9.95{ }^{\circ} \mathrm{C}$ for $\mathrm{C}_{3}$ species and $9.83{ }^{\circ} \mathrm{C}$ for graminoids; PRE8, mean August precipitation; PRE8 Break, a categorical separation of sites based on PRE8 of 145.7 mm for $\mathrm{C}_{3}$ species and $142.49 \mathrm{~mm}$ for graminoids; MS, mean squares; SS, proportion of variance explained by the variables. Bold values indicate statistical significance $(P<0.05)$. For $\mathrm{C}_{3}$ species, $\mathrm{r}^{2}=33.5$; for graminoids, $\mathrm{r}^{2}=29.9$; for forbs, $\mathrm{r}^{2}=19.1$; for shrubs, $\mathrm{r}^{2}=72.8$

species and graminoids, and the altitude pattern of shrub foliar $\delta^{15} \mathrm{~N}$ is induced by temperature (Figs. 3, 4 and 5).

\section{Discussion}

Potential mechanisms for enriched foliar $\delta^{15} \mathrm{~N}$ and variation of foliar $\delta^{15} \mathrm{~N}$ among PFGs

The mean value $\left(4.9 \%\right.$ ) of plant $\delta^{15} \mathrm{~N}$ in our study was higher than that of 2.4\%o obtained by Yang et al. (2013) on the Qinghai-Tibet Plateau. An explanation for this is that our study used leaves only whereas Yang et al. used all aboveground tissues including both leaves and stems. Previous research has indicated that intra-plant $\delta^{15} \mathrm{~N}$ variation was significant due to organ-specific loss of nitrogen, and resorption and reallocation of nitrogen (Evans 2001). Some research has shown that foliar $\delta^{15} \mathrm{~N}$ content can be 3 7\% higher than that of roots. It has been suggested that this is because $\mathrm{N}$ available for leaf assimilation is enriched relative to root as it originates from a pool that has already been exposed to root assimilation (Evans et al. 1996; Yoneyama and Kaneko 1989). Codron et al. (2005) observed that foliar $\delta^{15} \mathrm{~N}$ was $2.2 \%$ greater than tree bark. Moreover, Yang et al. (2015) found that $\delta^{15} \mathrm{~N}$ of alpine plants also varied substantially among the tissues, mostly by $>2 \%$. Although there are no direct comparisons between leaves and stems, the mechanisms and observations referred to support our assumption that foliar $\delta^{15} \mathrm{~N}$ is greater than that of stems.

Another consideration is that our sampling period (2004 2007) was later than that (2001 2004) of Yang et al. (2013). Chen et al. (2013) suggested that the Qinghai-Tibetan Plateau has experienced significant warming at the rate of $0.2{ }^{\circ} \mathrm{C}$ per decade since 1960 , and that the warming trend has even intensified since 2000. In addition, we have confirmed that foliar $\delta^{15} \mathrm{~N}$ of $\mathrm{C}_{3}$ species increased with TEM8 at $1.274 \%{ }^{\circ} \mathrm{C}^{-1}$ across sites with TEM $8 \geq 9.95^{\circ} \mathrm{C}$ on the Qinghai-Tibet Plateau (Fig. 3a). However, we suggest that sampling period is just a secondary explanation, as the increase of foliar $\delta^{15} \mathrm{~N}$ induced by warming is much less than the difference between our result and that of Yang et al. (2013).

Although the difference between foliar $\delta^{15} \mathrm{~N}$ of legumes and non-legumes is not consistent (Codron et al. 2005), we found that foliar $\delta^{15} \mathrm{~N}$ of legumes is markedly lower than that of non-legumes. One possible explanation is that legumes obtain nitrogen $(\mathrm{N})$ mainly by symbiotic $\mathrm{N}_{2}$ fixation, and the effect of discrimination against ${ }^{15} \mathrm{~N}$ during symbiotic $\mathrm{N}_{2}$ fixation is negligible. Thus legume foliar $\delta^{15} \mathrm{~N}$ is near to the $\delta^{15} \mathrm{~N}$ of air $\mathrm{N}_{2}(0$ $\pm 2 \%$ ) (Shearer and Kohl 1989). Non-legumes without symbiotic $\mathrm{N}_{2}$ fixation mainly obtain $\mathrm{N}$ by uptake by roots from soil, and compared with air, soil $\delta^{15} \mathrm{~N}$ is higher (Schmidt and Stewart 2003).

Our observation that foliar $\delta^{15} \mathrm{~N}$ of graminoids is higher than that of forbs (Table 1) is similar to that of previous studies, e.g., Dijkstra et al. (2003) found that foliar $\delta^{15} \mathrm{~N}$ of grasses was higher than that of forbs in a meadow on the San Francisco Peaks near Flagstaff, Arizona. Moreover, Yang et al. (2015) found that foliar $\delta^{15} \mathrm{~N}$ of the sedge Carex sempervirens was higher than that of the forbs Geum montanum and Homogyne alpina across 11 sampling sites in the Swiss Alps. Foliar $\delta^{15} \mathrm{~N}$ 

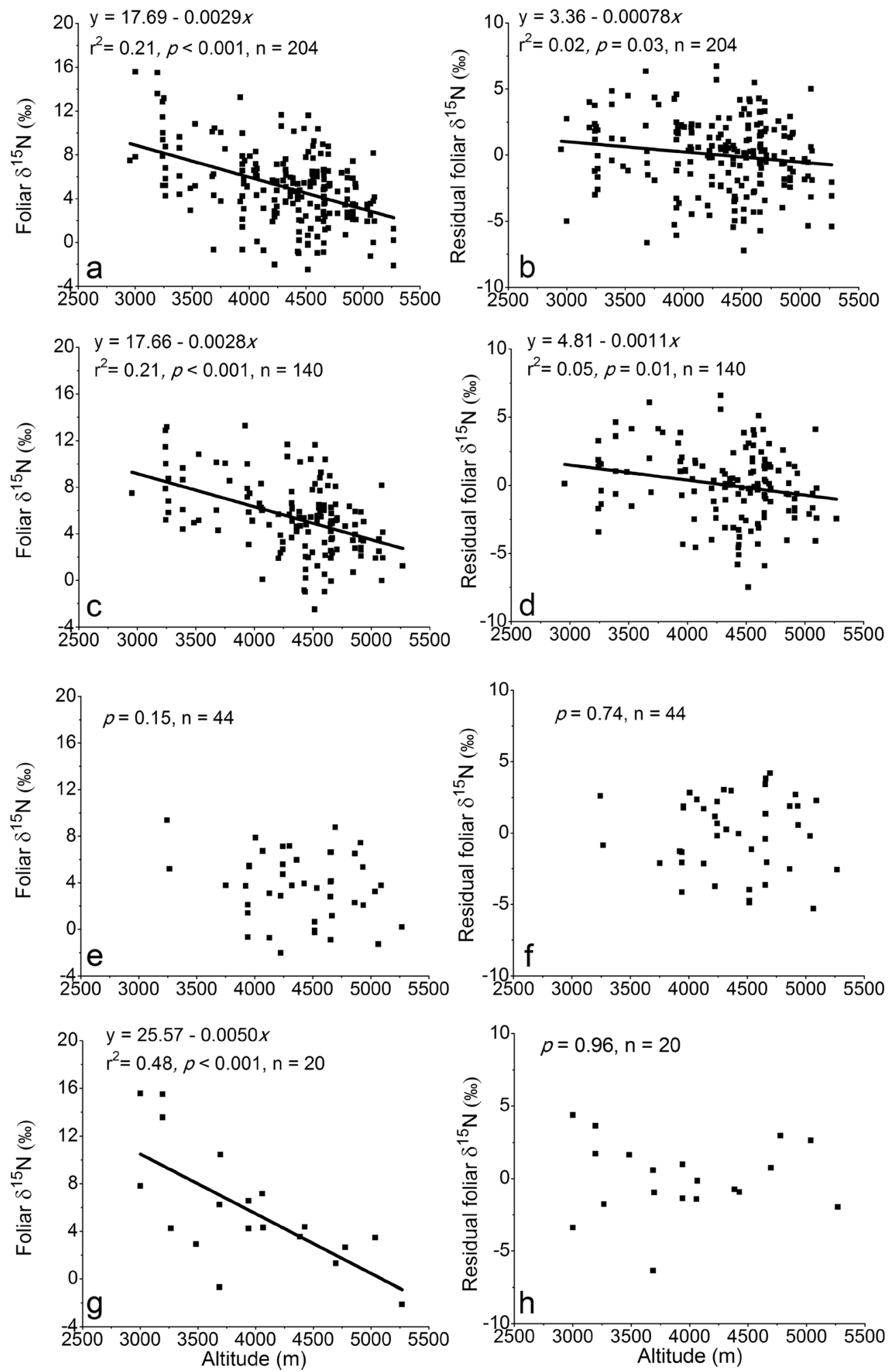

Fig. 5 Relationships between foliar $\delta^{15} \mathrm{~N}$ and altitude for plant functional groups (PFGs) on the Qinghai-Tibet Plateau before (a, $\mathbf{c}, \mathbf{e}, \mathbf{g})$ and after $(\mathbf{b}, \mathbf{d}, \mathbf{f}, \mathbf{h})$ residual foliar $\delta^{15} \mathrm{~N}$ were taken from

GLMs that included temperature and precipitation variables. $(\mathbf{a}, \mathbf{b})$ $\mathrm{C}_{3}$ species; (c, d) graminoids; (e, f) forbs; ( $\left.\mathbf{g}, \mathbf{h}\right)$ shrubs 
of shrubs was higher than forbs and graminoids, although the differences were not significant perhaps due to greater variation of foliar $\delta^{15} \mathrm{~N}$ for shrubs (Table 1). This result was consistent with the result obtained on the Inner Mongolia grassland by $\mathrm{Wu}$ and Huang (2010). Some studies have compared the difference of foliar $\delta^{15} \mathrm{~N}$ between herbs and shrubs and found foliar $\delta^{15} \mathrm{~N}$ of shrubs to be significantly higher than that of herbs (Liu et al. 2010). Thus, in order to compare our result with previous studies, we combined graminoids and forbs, and found the foliar $\delta^{15} \mathrm{~N}$ of shrubs to also be significantly higher than that of herbs on the QinghaiTibet Plateau $(p=0.01)$.

Differences of foliar $\delta^{15} \mathrm{~N}$ among life-forms are attributed to the characters of rooting depth, mycorrhiza, and the form of $\mathrm{N}$ absorbed. Plants with deeper roots can obtain $\mathrm{N}$ from deeper soil layers where soil $\delta^{15} \mathrm{~N}$ is greater (Ometto et al. 2006; Yang et al. 2015). Further, co-existing plants can utilize different $\mathrm{N}$ sources especially in N-limited environments, and this ability can be related to life form (Schulze et al. 1994; Wu and Huang 2010). Additionally, different $\mathrm{N}$ sources have different $\delta^{15} \mathrm{~N}$ and the general pattern is $\mathrm{NH}_{4}{ }^{+}-\mathrm{N}>\mathrm{NO}_{3}{ }^{-}-\mathrm{N}$ (Aranibar et al. 2008; Koba et al. 2003). Lastly, plants can obtain $\mathrm{N}$ via mycorrhiza, and this phenomenon is prevalent in $\mathrm{N}$-limited environments. The $\mathrm{N}$ that mycorrhiza transfer to plants is ${ }^{15} \mathrm{~N}$ depleted and plants associated with different mycorrhiza types have different foliar $\delta^{15} \mathrm{~N}$ (Amundson et al. 2003; Craine et al. 2009; Hobbie et al. 2005). All these aspects could be explanations for difference of foliar $\delta^{15} \mathrm{~N}$ among life forms observed on the Qinghai-Tibet Plateau. Therefore studies of root distribution, mycorrhiza and forms of $\mathrm{N}$ utilized by different life-form plants on the QinghaiTibet Plateau are required to understand differences of their $\delta^{15} \mathrm{~N}$.

Relationships between foliar $\delta^{15} \mathrm{~N}$ and temperature

Our observation that foliar $\delta^{15} \mathrm{~N}$ of $\mathrm{C}_{3}$ species and graminoids were not monotonically linearly related to temperature, with foliar $\delta^{15} \mathrm{~N}$ invariant across sites with low temperature but significantly increasing with temperature across warmer sites (Fig. 3a and b) was in concordance with the global pattern obtained by Craine et al. (2009). It is relevant to note that the relationships we observed were between foliar $\delta^{15} \mathrm{~N}$ and TEM8, whereas the relationship obtained by Craine et al. (2009) was between foliar $\delta^{15} \mathrm{~N}$ and MAT. Their suggestion that dissolved organic $\mathrm{N}$ (DON) becomes the dominant form of $\mathrm{N}$ loss in ecosystems with MAT $<-0.5{ }^{\circ} \mathrm{C}$ provides a possible explanation for foliar $\delta^{15} \mathrm{~N}$ being invariant at low temperatures, as there is little fractionation during DON solubilization and its loss should not lead to enrichment of the available $\mathrm{N}$ pool. We suggest this as an explanation for our observation that foliar $\delta^{15} \mathrm{~N}$ is invariant across sites with TEM $8<9.95{ }^{\circ} \mathrm{C}$ for $\mathrm{C}_{3}$ species and TEM $8<9.83{ }^{\circ} \mathrm{C}$ for graminoids, although we do not have direct evidence that DON was the dominant form of $\mathrm{N}$ loss from the $\mathrm{N}$ pool at these sites. In addition, foliar $\delta^{15} \mathrm{~N}$ increase with temperature has been attributed to increasing rates of gaseous $\mathrm{N}$ loss through ammonium volatilization, nitrification and denitrification with increasing temperature (Amundson et al. 2003; Craine et al. 2009). Clearly, future research determining nitrification and denitrification across temperature gradients could provide new insights into patterns of foliar $\delta^{15} \mathrm{~N}$ associated with increasing temperature.

Yang et al. (2013) found no significant trend between vegetation $\delta^{15} \mathrm{~N}$ and temperature on the Qinghai-Tibet Plateau. They attributed the inconsistency between their observation and previously reported temperature patterns to the narrow temperature range (MAT: -3 to $5{ }^{\circ} \mathrm{C}$ ) of their study, and suggested that the relationship between foliar $\delta^{15} \mathrm{~N}$ and MAT becomes weaker as the temperature range narrows. However, we consider that temperature range is just a secondary reason as our study area and temperature range were similar to those of Yang et al. (2013). Thus we suggest the different sampling strategies of the two studies as the main reason. Differing from ours and previous studies in which only leaf samples were analyzed, Yang et al. (2013) sampled all aboveground tissues including leaves, stems, flowers and seeds. Tissue type variations of $\delta^{15} \mathrm{~N}$ have been widely recorded (Codron et al. 2005; Evans 2001), and also specifically for an alpine region by Yang et al. (2015). Thus, tissue variation in $\delta^{15} \mathrm{~N}$ is likely to modify the relationship between $\delta^{15} \mathrm{~N}$ and temperature.

\section{Relationships between foliar $\delta^{15} \mathrm{~N}$ and precipitation}

Our observation that foliar $\delta^{15} \mathrm{~N}$ of forbs decreased with precipitation agrees with previous findings (Amundson et al. 2003; Craine et al. 2009; Peri et al. 2012; Swap et al. 2004). However, foliar $\delta^{15} \mathrm{~N}$ of $\mathrm{C}_{3}$ species significantly decreased with precipitation when PRE $8<$ $145.7 \mathrm{~mm}$, and showed no trend with precipitation when 
PRE8 $\geq 145.7 \mathrm{~mm}$ (Fig. 4a). An explanation is that gaseous $\mathrm{N}$ loss (such as ammonium volatilization and gaseous $\mathrm{N}$ loss through nitrification and denitrification) was the dominant form of $\mathrm{N}$ pool loss in sites with PRE8 $<145.7 \mathrm{~mm}$, and rates of gaseous $\mathrm{N}$ loss decreased with precipitation (Houlton et al. 2006), whereas leaching of nitrate was the dominant form of $\mathrm{N}$ pool loss for sites with PRE8 $\geq 145.7 \mathrm{~mm}$. Although discrimination does not occur during leaching, discrimination is significant during nitrification (Handley and Raven 1992). Thus leaching of nitrate causes ${ }^{15} \mathrm{~N}$ enrichment of the soil $\mathrm{N}$ pool and this effect increases with precipitation. Across sites with high precipitation, leaching of nitrate offsets the effect of gaseous $\mathrm{N}$ loss on soil and foliar $\delta^{15} \mathrm{~N}$, and leads to foliar $\delta^{15} \mathrm{~N}$ showing no trend with variation of precipitation. Moreover, in wetter sites, denitrification completely consuming nitrate prevents the expression of its isotope effect on soil and foliar $\delta^{15} \mathrm{~N}$ (Houlton et al. 2006). Thus this could be another explanation for foliar $\delta^{15} \mathrm{~N}$ being invariant with precipitation across high precipitation sites. Clearly these explanations require data on hydrologic and gaseous $\mathrm{N}$ losses across precipitation gradients in our study area to fully support them.

Relationships between foliar $\delta^{15} \mathrm{~N}$ and altitude

Altitude does not have a direct effect on foliar $\delta^{15} \mathrm{~N}$. Relationships shown with it are related to temperature, precipitation, atmospheric pressure (responsively atmospheric $\mathrm{CO}_{2}$ and $\mathrm{O}_{2}$ concentrations) and also soil physicochemical properties that change with altitude. Thus, the combined effects of these factors on foliar $\delta^{15} \mathrm{~N}$ will show as altitudinal patterns of foliar $\delta^{15} \mathrm{~N}$. Our finding that foliar $\delta^{15} \mathrm{~N}$ decreased with increased altitude was consistent with most previous studies, and this trend was mostly accounted for by temperature and precipitation effects on foliar $\delta^{15} \mathrm{~N}$ by their influence on soil $\mathrm{N}$ availability and rates of gaseous $\mathrm{N}$ losses (Averill and Finzi 2011; Liu et al. 2007; Sah and Brumme 2003). This is the case for shrubs (Fig. $5 \mathrm{~g}$ and $\mathrm{h}$ ). However, after precipitation and temperature were taken into account, altitude still exerted an effect on foliar $\delta^{15} \mathrm{~N}$ for $\mathrm{C}_{3}$ species and graminoids (Fig. $5 \mathrm{~b}$ and d).

While acknowledging dominating influences of precipitation and temperature related to altitude, atmospheric $\mathrm{CO}_{2}$ concentration even more inherently changes with altitude. Previous studies show that atmospheric $\mathrm{CO}_{2}$ concentrations have effects on key processes of the $\mathrm{N}$ cycle and soil $\mathrm{N}$ availability (Gill et al. 2002; Horz et al. 2004; Taylor and Ball 1994; Zak et al. 1993). Although the effect of elevated atmospheric $\mathrm{CO}_{2}$ concentration on soil $\mathrm{N}$ availability has been controversial, with some showing increasing (Taylor and Ball 1994; Zak et al. 1993) and some decreasing (Gill et al. 2002; Horz et al. 2004; Billings et al. 2002) responses, the predominant pattern has been that elevated $\mathrm{CO}_{2}$ decreases soil $\mathrm{N}$ availability. Bassirirad et al. (2003) found that foliar $\delta^{15} \mathrm{~N}$ decreased with elevated $\mathrm{CO}_{2}$ whereas Billings et al. (2002) observed the converse response. From these contradictory results, based on the declining trend of foliar $\delta^{15} \mathrm{~N}$ with increased altitude (Fig. 5), and inferred decreased $\mathrm{CO}_{2}$ concentration, that we observed, it cannot be conclusively concluded that atmospheric $\mathrm{CO}_{2}$ concentration is a key driving factor for the altitudinal pattern of foliar $\delta^{15} \mathrm{~N}$. Soil factors, such as soil $\mathrm{pH}$ and texture and mycorrhizal associations, could be driving factors for the altitudinal pattern of foliar $\delta^{15} \mathrm{~N}$.

PFGs foliar $\delta^{15} \mathrm{~N}$ responses to climate factors

In contrast to the global pattern that foliar $\delta^{15} \mathrm{~N}$ of $\mathrm{N}_{2^{-}}$ fixing plant is related to temperature and unrelated to precipitation (Craine et al. 2009), we found that relationships between foliar $\delta^{15} \mathrm{~N}$ and climate factors occurred for non-legumes but not for legumes (data not shown). The most likely explanation is that the ability of legumes to biologically fix atmospheric $\mathrm{N}$ makes them independent of variations of soil $\delta^{15} \mathrm{~N}$. Thus, their foliar $\delta^{15} \mathrm{~N}$ is not affected by variations in soil $\mathrm{N}$ cycling and soil $\delta^{15} \mathrm{~N}$ caused by climate factors. The different responses of life-form foliar $\delta^{15} \mathrm{~N}$ to climate factors accord with findings at Dongling Mountain, China by Liu et al. (2010). This indicates different life forms have specific $\mathrm{N}$ metabolic process responses across climate gradients. Further study on the effects of climate factors on plant $\mathrm{N}$ metabolic process (e.g., nitrogen assimilation nitrate reductase and glutamine synthetase) across climate gradients are needed to provide new insights into the difference of foliar $\delta^{15} \mathrm{~N}$ among PFGs in response to climate factors.

\section{Conclusions}

In examining relationships between foliar $\delta^{15} \mathrm{~N}$ and temperature and precipitation, this study has established that these relationships are better defined using climate data during peak annual growth, and in some instances 
by piecewise linear regression. It has also shown that PFGs differ in their foliar $\delta^{15} \mathrm{~N}$ relationships with climate factors. The study indicates that further systematic study of hydrologic and gaseous $\mathrm{N}$ losses, mycorrhizal associations and plant $\mathrm{N}$ metabolic processes across climate gradients are needed to provide new insights into the determination of variation of foliar $\delta^{15} \mathrm{~N}$ linked with temperature and precipitation in order to understand the basis of differences of these patterns. In particular there is a specific need to identify factors other than temperature and precipitation, e.g., soil $\mathrm{pH}$ and texture, atmospheric gas concentrations and mycorrhizal associations, which may determine the reduction of foliar $\delta^{15} \mathrm{~N}$ of $\mathrm{C}_{3}$ species and graminoids as altitude increases in the uniquely high altitude Qinghai-Tibet region.

Acknowledgements The research was funded by the National Natural Science Foundation of China (grant no. 31400413, 31070427), Scientific Research Starting Foundation for Young Teachers, Northeastern University of China (grant no. N130301001), the Doctoral Startup Foundation of Liaoning Province (grant no. 20141017), National Key Technologies R\&D Program of the Ministry of Science and Technology of the People's Republic of China (grant no. 2013BAC03B04), and the National Key Basic Research Program of China (2010CB950902). We thank Lupeng Gao, Lulu Song and Bin Han for field work and Wenyan Zhang for sample analysis.

\section{References}

Amundson R, Austin A, Schuur E, Yoo K, Matzek V, Kendall C, Uebersax A, Brenner D, Baisden W (2003) Global patterns of the isotopic composition of soil and plant nitrogen. Glob Biogeochem Cy 17:1031. doi:10.1029/2002GB001903

Aranibar JN, Anderson IC, Epstein HE, Feral CJW, Swap RJ, Ramontsho J, Macko SA (2008) Nitrogen isotope composition of soils, $\mathrm{C}_{3}$ and $\mathrm{C}_{4}$ plants along land use gradients in southern Africa. J Arid Environ 72:326-337. doi:10.1016/j. jaridenv.2007.06.007

Averill C, Finzi A (2011) Increasing plant use of organic nitrogen with elevation is reflected in nitrogen uptake rates and ecosystem $\delta^{15} \mathrm{~N}$. Ecology 92:883-891. doi:10.1890/10-0746.1

Bassirirad H, Constable JVH, Lussenhop J, Kimball BA, Norby RJ, Oechel WC, Reich PB, Schlesinger WH, Zitzer S, Sehtiya HL, Silim S (2003) Widespread foliage $\delta^{15} \mathrm{~N}$ depletion under elevated $\mathrm{CO}_{2}$ : inferences for the nitrogen cycle. Glob Chang Biol 9:1582-1590. doi:10.1046/j.1365-2486. 2003.00679.x

Billings SA, Schaeffer SM, Zitzer S, Charlet T, Smith SD, Evans RD (2002) Alterations of nitrogen dynamics under elevated carbon dioxide in an intact mojave desert ecosystem: evidence from nitrogen-15 natural abundance. Oecologia 131:463-467. doi:10.1007/s00442-002-0898-4

Chen H, Zhu Q, Peng C, Wu N, Wang Y, Fang X, Gao Y, Zhu D, Yang G, Tian J (2013) The impacts of climate change and human activities on biogeochemical cycles on the QinghaiTibetan Plateau. Global Change Biol 19:2940-2955. doi:10. 1111/gcb.12277

Codron J, Codron D, Lee-Thorp J, Sponheimer M, Bond W, de Ruiter D, Grant R (2005) Taxonomic, anatomical, and spatiotemporal variations in the stable carbon and nitrogen isotopic compositions of plants from an African savanna. J Archaeol Sci 32:1757-1772. doi:10.1016/j.jas.2005.06.006

Craine JM, Elmore AJ, Aidar MPM, Bustamante M, Dawson TE, Hobbie EA, Kahmen A, Mack MC, McLauchlan KK, Michelsen A, Nardoto GB, Pardo LH, Penuelas J, Reich PB, Schuur EAG, Stock WD, Templer PH, Virginia RA, Welker JM, Wright IJ (2009) Global patterns of foliar nitrogen isotopes and their relationships with climate, mycorrhizal fungi, foliar nutrient concentrations, and nitrogen availability. New Phytol 183:980-992. doi:10.1111/j.1469-8137.2009. 02917.x

Dijkstra P, Williamson C, Menyailo O, Doucett R, Koch G, Hungate B (2003) Nitrogen stable isotope composition of leaves and roots of plants growing in a forest and a meadow. Isot Environ Health Stud 39:29-39. doi:10.1080/ 1025601031000102189

Evans R (2001) Physiological mechanisms influencing plant nitrogen isotope composition. Trends Plant Sci 6:121-126. doi: 10.1016/S1360-1385(01)01889-1

Evans R, Bloom A, Sukrapanna S, Ehleringer J (1996) Nitrogen isotope composition of tomato (Lycopersicon esculentum Mill. cv. T-5) grown under ammonium or nitrate nutrition. Plant Cell Environ 19:1317-1323. doi:10.1111/j.1365-3040. 1996.tb00010.x

Fang Y, Koba K, Yoh M, Makabe A, Liu X (2013) Patterns of foliar $\delta^{15} \mathrm{~N}$ and their control in Eastern Asian forests. Ecol Res 28:735-748. doi:10.1007/s11284-012-0934-8

Fu BJ, Niu D, Zhao SD (2005) Study on global change and terrestrial ecosystems: history and prospect. Adv Earth Sci 20:556-560

Gill RA, Polley HW, Johnson HB, Anderson LJ, Maherali H, Jackson RB (2002) Nonlinear grassland responses to past and future atmospheric $\mathrm{CO}_{2}$. Nature 417:279-282

Handley L, Raven J (1992) The use of natural abundance of nitrogen isotopes in plant physiology and ecology. Plant Cell Environ 15:965-985

Hobbie E, Jumpponen A, Trappe J (2005) Foliar and fungal ${ }^{15} \mathrm{~N}:{ }^{14} \mathrm{~N}$ ratios reflect development of mycorrhizae and nitrogen supply during primary succession: testing analytical models. Oecologia 146:258-268

Horz HP, Barbrook A, Field CB, Bohannan BJM (2004) Ammonia-oxidizing bacteria respond to multifactorial global change. Proc Natl Acad Sci U S A 101:15136-15141. doi:10. 1073/pnas.0406616101

Houlton B, Sigman D, Hedin L (2006) Isotopic evidence for large gaseous nitrogen losses from tropical rainforests. Proc Natl Acad Sci U S A 103:8745-8750. doi:10.1073/pnas. 0510185103

Houlton BZ, Sigman DM, Schuur EAG, Hedin LO (2007) A climate-driven switch in plant nitrogen acquisition within 
tropical forest communities. Proc Natl Acad Sci U S A 104: 8902-8906. doi:10.1073/pnas.0609935104

IPCC (2007) Climate change 2007: synthesis report. Intergovernmental panel on climatic change. Cambrige University Press, Cambrige

Koba K, Hirobe M, Koyama L, Kohzu A, Tokuchi N, Nadelhoffer KJ, Wada E, Takeda H (2003) Natural ${ }^{15} \mathrm{~N}$ abundance of plants and soil $\mathrm{N}$ in a temperate coniferous forest. Ecosystems 6:457-469. doi:10.1007/s10021-002-0132-6

Liu X, Zhao L, Gasaw M, Gao D, Qin D, Ren J (2007) Foliar $\delta^{13} \mathrm{C}$ and $\delta{ }^{15} \mathrm{~N}$ values of $\mathrm{C}_{3}$ plants in the Ethiopia Rift Valley and their environmental controls. Chin Sci Bull 52:1265-1273. doi:10.1007/s11434-007-0165-5

Liu X, Wang G, Li J, Wang Q (2010) Nitrogen isotope composition characteristics of modern plants and their variations along an altitudinal gradient in Dongling Mountain in Beijing. Sci China Ser D Earth Sci 53:128-140. doi:10. 1007/s11430-009-0175-z

Mayor JR, Wright SJ, Schuur EA, Brooks ME, Turner BL (2014) Stable nitrogen isotope patterns of trees and soils altered by long-term nitrogen and phosphorus addition to a lowland tropical rainforest. Biogeochemistry 119:293-306. doi:10. 1007/s10533-014-9966-1

Ometto JPHB, Ehleringer JR, Domingues TF, Berry JA, Ishida FY, Mazzi E, Higuchi N, Flanagan LB, Nardoto GB, Martinelli LA (2006) The stable carbon and nitrogen isotopic composition of vegetation in tropical forests of the Amazon Basin, Brazil. Biogeochemistry 79:251-274. doi:10.1007/ 978-1-4020-5517-1_12

Peri PL, Ladd B, Pepper DA, Bonser SP, Laffan SW, Amelung W (2012) Carbon $\left(\delta^{13} \mathrm{C}\right)$ and nitrogen $\left(\delta^{15} \mathrm{~N}\right)$ stable isotope composition in plant and soil in Southern Patagonia's native forests. Glob Chang Biol 18:311-321. doi:10.1111/j.13652486.2011.02494.x

Robinson D (2001) $\delta^{15} \mathrm{~N}$ as an integrator of the nitrogen cycle. Trends Ecol Evol 16:153-162. doi:10.1016/S0169-5347(00) 02098-X

Sah S, Brumme R (2003) Altitudinal gradients of natural abundance of stable isotopes of nitrogen and carbon in the needles and soil of a pine forest in Nepal. J For Sci 49:19-26
Schmidt S, Stewart G (2003) $\delta^{15} \mathrm{~N}$ values of tropical savanna and monsoon forest species reflect root specialisations and soil nitrogen status. Oecologia 134:569-577. doi:10.1007/ s00442-002-1150-y

Schulze E, Chapin F, Gebauer G (1994) Nitrogen nutrition and isotope differences among life forms at the northern treeline of Alaska. Oecologia 100:406-412

Shearer G, Kohl D (1989) ESTIMATES of $\mathrm{n}_{2}$ fixation in ecosystems: the need for and basis of the ${ }^{15} \mathrm{~N}$ natural abundance method. In: Rundel P, Ehleringer J, Nagy K (eds) Stable isotopes in ecological research. Springer, Berlin, pp 342-374

Swap R, Aranibar J, Dowty P, Gilhooly W III, Macko S (2004) Natural abundance of ${ }^{13} \mathrm{C}$ and ${ }^{15} \mathrm{~N}$ in $\mathrm{C}_{3}$ and $\mathrm{C}_{4}$ vegetation of southern Africa: patterns and implications. Glob Chang Biol 10:350-358. doi:10.1046/j.1529-8817.2003.00702.x

Taylor J, Ball A (1994) The effect of plant material grown under elevated $\mathrm{CO}_{2}$ on soil respiratory activity. Plant Soil 162:315318. doi:10.1007/BF01347720

Wu TX, Huang JH (2010) Effects of grazing on the $\delta^{15} \mathrm{~N}$ values of foliage and soil in a typical steppe ecosystem in Inner Mongolia, China. Chin J Plant Ecol 34:160-169. doi:10. 3773/j.issn.1005-264x.2010.02.007

Yang Y, Ji C, Robinson D, Zhu B, Fang H, Shen H, Fang J (2013) Vegetation and soil ${ }^{15} \mathrm{~N}$ natural abundance in alpine grasslands on the Tibetan Plateau: patterns and implications. Ecosystems 16:1013-1024. doi:10.1007/s10021-013-9664-1

Yang Y, Siegwolf RTW, Koerner C (2015) Species specific and environment induced variation of $\delta^{13} \mathrm{C}$ and $\delta^{15} \mathrm{~N}$ in alpine plants. Front Plant Sci 6:423. doi:10.3389/fpls.2015.00423

Yoneyama T, Kaneko A (1989) Variations in the natural abundance of ${ }^{15} \mathrm{~N}$ in nitrogenous fractions of komatsuna plants supplied with nitrate. Plant Cell Physiol 30:957-962

Zak DR, Pregitzer KS, Curtis PS, Teeri JA, Fogel R, Randlett DL (1993) Elevated atmospheric $\mathrm{CO}_{2}$ and feedback between carbon and nitrogen cycles. Plant Soil 151:105-117. doi:10. 1007/BF00010791

Zhou YC, Fan JW, Harris W, Zhong HP, Zhang WY, Cheng XL (2013) Relationships between $C_{3}$ plant foliar carbon isotope composition and element contents of grassland species at high altitudes on the Qinghai-Tibet Plateau, China. Plos One 8:e60794. doi:10.1371/journal.pone.0060794 